\title{
Malignant aetiology for breathlessness, concealed by a perception of 'exam-anxiety'
}

\author{
Swaroop Revannasiddaiah, ${ }^{1}$ Muninder K Negi, ${ }^{2}$ Sridhar Papaiah Susheela, ${ }^{1}$ \\ Manoj Kumar Gupta ${ }^{3}$
}

1 Department of Radiation Oncology, HealthCare GlobalBangalore Institute of Oncology, Bengaluru, Karnataka, India

${ }^{2}$ Department of Radiotherapy, Dr Rajendra Prasad

Government Medical College, Tanda, Himachal Pradesh, India

${ }^{3}$ Department of Radiotherapy \& Oncology, Regional Cancer Centre, Indira Gandhi Medical College, Shimla, Himachal Pradesh, India

\section{Correspondence to} Dr Swaroop Revannasiddaiah, swarooptheone@gmail.com

\section{DESCRIPTION}

A 14-year-old boy student who had his annual exams (academic examinations) approaching, suffered a documented history of generalised anxiety disorder, which would occasionally exacerbate during periods of perceived stress, such as with exams. Prior to previous exams, he had for many years reported of having faced a temporary cluster of symptoms comprising palpitations, insomnia and breathlessness.

Just two months prior to his most recent exams, he reported to have felt the same symptom-cluster again, including breathlessness. Without any medical consultation, he attributed his symptoms to one of 'his usual anxiety attacks'. Moreover, the student lived away from his family, and he never discussed his symptoms with his family.

However, a week prior to his exams, he was brought to the emergency department complaining of being unable to breathe or to swallow. Evaluation with imaging promptly identified the cause for his current symptoms-a large mediastinal mass (figure 1), which was subsequently diagnosed to be a diffuse-large B-cell lymphoma.

The mass (measuring $1365 \mathrm{cc}$ in volume) had significantly reduced the volume of the right lung (to about $740 \mathrm{cc}$; figure 2), and also seemed to occupy some space in the left hemithorax too. There was also obvious evidence of mechanical compression of the trachea (figure 3 ).



Figure $1 \mathrm{CT}$ reconstruction of a coronal section across the mid-axillary area depicting the mass (blue arrow) involving the mediastinum and the right hemithorax.
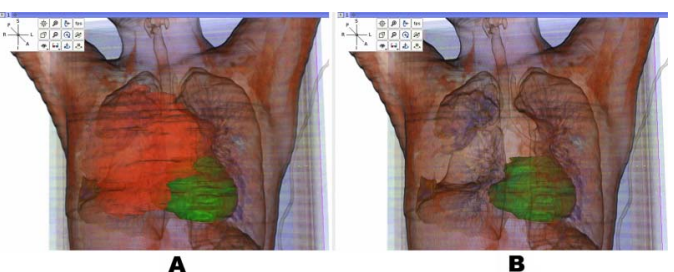

Figure 2 Volumetric reconstruction (A) depicting the large size of the mediastinal mass (red), in relation to the heart (green) and the lungs. The extent of lung-volume reduction owing to the compression by the mass has been demonstrated by rendering the mass invisible (B).

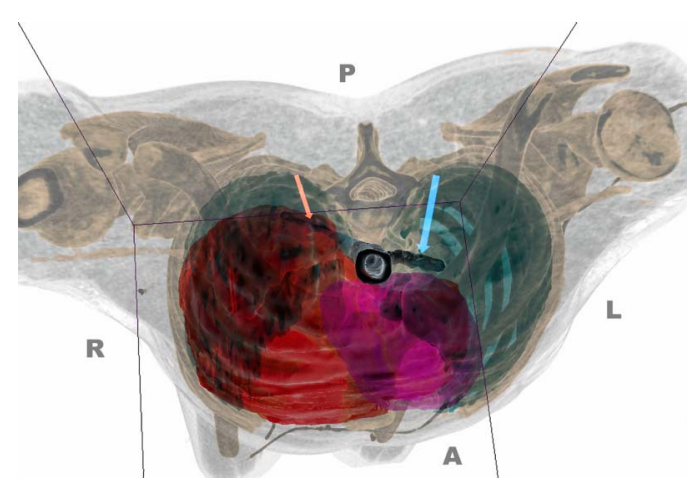

Figure 3 Volumetric reconstruction depicting the marked compression of the right bronchus (orange arrow) by the mass (red volume). In comparison, the left bronchus (blue arrow) is seen to be uncompressed and hence of normal calibre. The pink volume represents the heart, and the cyan volumes represents the lungs.

This case illustrates the necessity for adequate clinical suspicion towards alternate diagnoses, even in situations wherein a previous diagnosis seems adequate enough to explain the current symptom complex. While anxiety is known to induce symptoms such as dyspnoea, it is also a well-known fact that a mass in the mediastinum too can cause the same. $^{1} 2$

\section{Learning points}

- It is important to look for alternate diagnoses even if a previous diagnosis seems adequate as an explanation for the symptoms.

- Lymphomas are one of the most rapidly growing malignancies, with a rapid progression within a period of weeks being quite common. ${ }^{3}$ 
Competing interests None.

Patient consent Obtained.

Provenance and peer review Not commissioned; externally peer reviewed.

\section{REFERENCES}

1 Bass C, Gardner W. Emotional influences on breathing and breathlessness. J Psychosom Res 1985;29:599-609.
2 Chen DB, Wang Y, Song QJ, et al. Clinicopathologic study of 40 cases of mediastinal tumours of haematopoietic and lymphoid tissues. Zhonghua Bing Li Xue Za Zhi 2012:41:376-81.

3 Ferry JA. Burkitt's lymphoma: clinicopathologic features and differential diagnosis. Oncologist 2006;11:375-83.

Copyright 2013 BMJ Publishing Group. All rights reserved. For permission to reuse any of this content visit http://group.bmj.com/group/rights-licensing/permissions.

BMJ Case Report Fellows may re-use this article for personal use and teaching without any further permission.

Become a Fellow of BMJ Case Reports today and you can:

- Submit as many cases as you like

- Enjoy fast sympathetic peer review and rapid publication of accepted articles

- Access all the published articles

- Re-use any of the published material for personal use and teaching without further permission

For information on Institutional Fellowships contact consortiasales@bmjgroup.com

Visit casereports.bmj.com for more articles like this and to become a Fellow 